Original Article

\title{
OPTIMIZATION OF POMEGRANATE PEEL EXTRACTS FOR THE BIOCONVERSION OF THE ELLAGITANNINS TO ELLAGIC ACID USING ASPERGILLUS NIGER, RHIZOPUS ORYZAE AND MIXED CULTURE
}

\author{
SUNDARALINGAM R. , NIREN ANDREW S. ${ }^{*}$, PREMINA $S .{ }^{*}$ \\ *Department of Microbiology, Madras Christian College (Autonomous), Chennai, Tamil Nadu, India 600059 \\ Email: nirenandrew@mcc.edu.in
}

Received: 12 Apr 2021, Revised and Accepted: 02 Jun 2021

\section{ABSTRACT}

Objective: The present study is aimed at optimization of concentration of substrate (pomegranate peel extract) for the production of Ellagic acid using Aspergillus niger and Rhizopus oryzae.

Methods: Test organisms were isolated and identified using standard microbiological techniques. Collected pomegranate peels were dried, grained and used as the substrate for solid-state fermentation. Prepared spore suspension of the test organisms was inoculated and incubated at room temperature. At regular intervals of $24 \mathrm{~h}$, samples were drawn and subjected to analysis of reducing sugar, soluble proteins, hydrolysable tannins and production of extracellular tannase using standard methods.

Results: The results of the present investigation demonstrated the optimum substrate concentration for the active conversion of ellagitannins to ellagic was $15 \mathrm{~g}$ of $A$. niger, $20 \mathrm{~g}$ for R. oryzae and $15 \mathrm{~g}$ for mixed culture.

Conclusion: From the current work, it was concluded that solid-state bioprocessing of fruit substrates and fruit wastes using fungi has shown to enrich phenolic antioxidants and improve phytochemical consistency.

Keywords: Ellagic acid, Ellagitannins, Pomegranate peel extract, Antioxidant

(C) 2021 The Authors. Published by Innovare Academic Sciences Pvt Ltd. This is an open access article under the CC BY license (https://creativecommons.org/licenses/by/4.0/) DOI: https://dx.doi.org/10.22159/ijpps.2021v13i8.41782. Journal homepage: https://innovareacademics.in/journals/index.php/ijpps.

\section{INTRODUCTION}

Bioactive compounds production using biotechnological methods has gained great momentum in recent years. Bioconversion is one of the biotechnological methods which are used to reduce the cost and pollution in the production of bioactive compounds from horticultural wastes. Fruit wastes such as peels, pulp and seeds are the major source of horticultural wastes. The pomegranate juice industry generates large amounts of peel wastes during the production of juice. Polyphenolic compounds stand out in the production of bioactive compounds from plants. These polyphenolic compounds play a significant role in the production of several food supplements that possess a lot of health benefits such as anti-carcinogenicity, antimutagenicity and antioxidant properties.

Ellagitannins are a group of polyphenolic compounds which is present abundantly in the pomegranate peel wastes. This pomegranate peel has been traditional used in folklore medicine for the treatment of diarrhea and dysentery. Pomegranate peel possesses higher content of polyphenols. This part contains ellagitannins and ellagic acid. Ellagitannins are hydrolyzed to ellagic acid in the gut, thus resulting in a prolonged release of this acid into the blood [1]. These Ellagitannins are hydrolyzable polyphenolic compounds that possess antioxidant properties which are used to prevent degenerative diseases such as cancer and cardiovascular diseases. Among the various groups of microorganisms, filamentous fungi dominate in the production of tannase enzyme, which in turn is used for bioconversion of Ellagitannins to Ellagic acid.

Filamentous fungi such as Aspergillus niger, Aspergillus foetidus, Aspergillus awamori, Rhizopus oryzae, Penicillium montanense, Trichoderma reesi were found to produce tannase enzyme which could be used for bioconversion of Ellagitannins to Ellagic acid. Several fermentation systems have been developed for the production of tannase from fungi using various production media. These systems can be divided into liquid surface fermentation (LSF), submerged fermentation (SmF), solid-state fermentation (SSF) and modified solid-state fermentation, MSSF $[2,3]$.
Recently, Ellagic acid has been receiving the most attention because of its wide array of biological properties, such as radical scavenging, chemopreventive, antiviral and antibacterial properties [4]. Ellagic acid is a polyphenol antioxidant found in numerous fruits and vegetables including blackberries, raspberries, strawberries, cranberries, walnuts, pecans, pomegranates, wolfberry and other plant foods. Ellagic acid was discovered by Braconnot in 1831. The antiproliferative and antioxidant properties of ellagic acid have spurred preliminary research into the potential health benefits of ellagic acid consumption. The highest levels of ellagic acid are found in raspberries. In plants, ellagic acid is present in the form of ellagitannin [5]. Ellagic acid is an anti-mutagenic and anticarcinogen starter. Some studies suggested that Ellagic acid decreased the abnormal cell growth in the human colon, prevented the development of cells infected with human papillomavirus (VPH), which is related to cervical cancer and promoted the apoptotic growth (natural death) of cancerous cells of the prostate. Sultana Shaikh and Vandana Jain [6] reported the use of Ellagic acid and quercetin in ayurvedic dental powder and its therapeutic activity. They developed HPLC method for the determination of ellagic acid and quercetin in the ayurvedic dental powder. Apart from this, ellagic acid was found to possess high biological activity against number of pathogens such as Staphylococcus epidermatis, Bacillus cereus, Klebsiella pneumonia, Salmonella typhi, etc [7].

In previous studies, it has been demonstrated that Aspergillus niger and Rhizopus oryzae are used for the bioconversion of ellagitannins present in pomegranate peel extract to ellagic acid. Hence, the present investigation involves the optimization of substrate concentration-Pomegranate peel extract for Ellagic acid production using A. niger and R. oryzae through solid-state fermentation.

\section{MATERIALS AND METHODS}

Isolation and Identification of test organisms

Soil samples were collected from various areas of Madras Christian College campus. Collected soil samples were serial diluted and spread 
plated on Sabouraud Dextrose Agar (SDA) and incubated at $25^{\circ} \mathrm{C}$ for $72 \mathrm{~h}$. After incubation the samples were subjected to lactophenol cotton blue staining and identified as Aspergillus niger and Rhizopus oryzae based on both microscopic and macroscopic observation. After identification, the test organisms were sub-cultured in Czapek-dox medium plates containing $1 \%$ tannic acid for further use [8].

\section{Preparation of spore suspension}

Sub-cultured mycelial growth of test organisms on Czapek-dox medium containing 1\% tannic acid were collected using Tween $80(0.1 \%)$ along with $10 \mathrm{ml}$ of sterile distilled water. The spore suspension was agitated in vortex for $5 \mathrm{~min}$ and used for inoculum preparation [9].

\section{Induced inoculum preparation}

$100 \mathrm{ml}$ of $1 \%$ tannic acid in Czapek-dox liquid medium was prepared in a conical flask and autoclaved. To this $10 \mathrm{ml}$ of prepared spore suspension was added and then incubated at room temperature $\left(27\right.$ to $\left.30^{\circ} \mathrm{C}\right)[10]$.

\section{Preparation of substrate}

Pomegranate fruits were collected from nearby local fruit shop and their peels were extracted. These peels were suspended on trays and oven-dried at $70{ }^{\circ} \mathrm{C}$ for $24 \mathrm{~h}$. The dried peels were ground and sieved to obtain a particle size of $425 \mathrm{~mm}$ and stored in sterile polyethylene bags at room temperature $\left(30-35^{\circ} \mathrm{C}\right)[11]$.

\section{Solid-state fermentation}

Czapek-dox liquid medium was prepared in 15 different Erlenmeyer flasks for 3 different test cultures- $A$. niger, $R$. orzyae and Mixed culture. $5 \mathrm{~g}, 10 \mathrm{~g}, 15 \mathrm{~g}, 20 \mathrm{~g}, 25 \mathrm{~g}$ of the substrate was weighed and added to the prepared 3 sets of Czapek-dox liquid medium flasks. $\mathrm{pH}$ of the medium was adjusted to 4.5 to 5 using Hydrochloric acid or Sodium hydroxide and the flasks were autoclaved. To this autoclaved medium, $10 \mathrm{ml}$ of prepared spore suspension of test cultures were added and incubated at room temperature [12].

\section{Physiochemical characterization}

At regular intervals of $24 \mathrm{~h}$, samples were drawn and subjected to analysis of reducing sugar, soluble proteins, hydrolyzable tannins and production of extracellular tannase using standard methods. Reducing sugar was estimated using Di-Nitro Salicylic (DNS) Acid method; Tannase enzyme activity was determined by the method of Mondal [13]; soluble proteins was estimated by Lowry method and hydrolysable tannin estimation was done by Folin-Ciocalteau method.

Table 1: Estimation of sugar concentration (mg) during fermentation of various concentrations of substrate using Aspergillus niger

\begin{tabular}{|c|c|c|c|c|c|c|}
\hline \multirow[t]{2}{*}{ S. No. } & \multirow[t]{2}{*}{ Incubation time in days } & \multicolumn{5}{|c|}{ Substrate concentration (g) } \\
\hline & & 5 & 10 & 15 & 20 & 25 \\
\hline 1 & 0 & 0.46 & 0.67 & 0.71 & 0.72 & 0.55 \\
\hline 2 & 1 & 0.51 & 0.74 & 0.82 & 0.97 & 0.74 \\
\hline 3 & 2 & 0.54 & 0.86 & 0.94 & 1.12 & 0.93 \\
\hline 4 & 3 & 0.61 & 0.97 & 1.12 & 1.47 & 1.08 \\
\hline 5 & 4 & 0.69 & 1.14 & 1.35 & 1.73 & 1.14 \\
\hline 6 & 5 & 0.73 & 1.31 & 1.57 & 2.07 & 1.21 \\
\hline 7 & 6 & 0.81 & 1.43 & 1.92 & 2.43 & 1.29 \\
\hline 8 & 7 & 0.93 & 1.50 & 2.04 & 2.71 & 1.46 \\
\hline 9 & 8 & 1.02 & 1.67 & 2.64 & 2.93 & 1.57 \\
\hline 10 & 9 & 1.08 & 1.98 & 3.01 & 3.04 & 1.83 \\
\hline 11 & 10 & 1.11 & 2.07 & 3.06 & 3.07 & 2.11 \\
\hline 12 & 11 & 1.19 & 2.04 & 2.98 & 2.81 & 1.97 \\
\hline 13 & 12 & 1.22 & 1.79 & 2.64 & 2.62 & 1.71 \\
\hline 14 & 13 & 1.02 & 1.61 & 2.01 & 2.01 & 1.12 \\
\hline 15 & 14 & 0.91 & 1.11 & 1.93 & 1.81 & 1.07 \\
\hline 16 & 15 & 0.73 & 0.95 & 1.31 & 1.12 & 0.87 \\
\hline
\end{tabular}

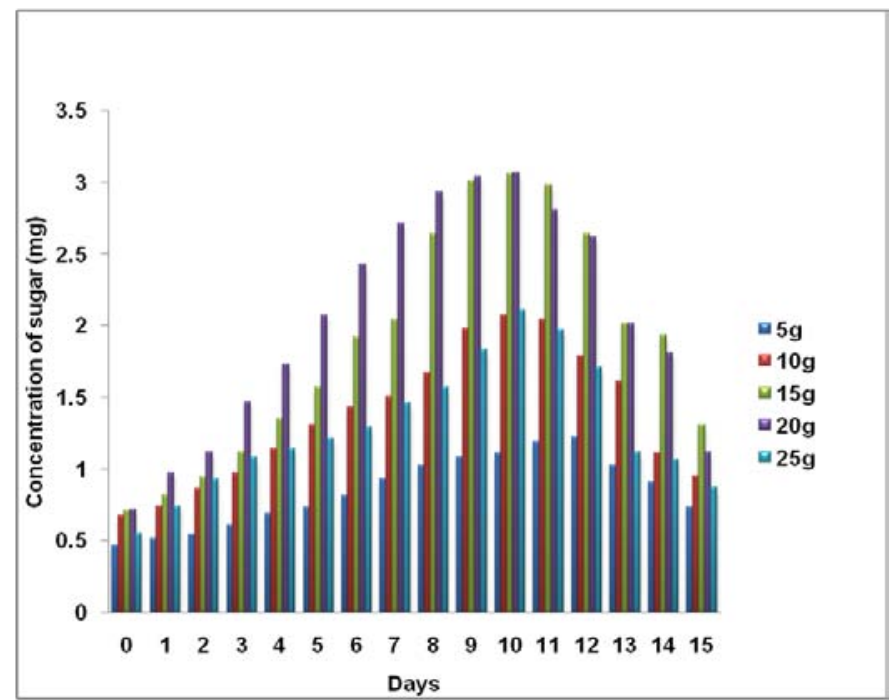

Fig. 1: Estimation of the concentration of sugar (mg) during fermentation of various concentrations of substrate using Aspergillus niger

\section{RESULTS AND DISCUSSION}

Ellagitannins and ellagic acid have been studied mainly for their positive effect on human health and their physiological properties such as anti-tumor, antiviral and antioxidant activities. Industrially ellagic acids are used in creams and other cosmetic products. Solidstate bioprocessing of fruit substrates and fruit wastes using fungus 
has shown to enrich phenolic antioxidants and improve phytochemical consistency. This increase in phenolic and antioxidant activity could have been due to the production of various hydrolyzing enzymes by the fungi during solid-state growth.

The main objective of the present work was to optimize the substrate concentration for the production of ellagic acid from pomegranate peel extracts by solid-state fermentation using A. niger, $R$. oryzae and mixed cultures.

The solid-state fermentation was carried out at different substrate concentrations such as $5 \mathrm{~g}, 10 \mathrm{~g}, 15 \mathrm{~g}, 20 \mathrm{~g}$, and $25 \mathrm{~g}$. The changes in the chemical composition of pomegranate peels were evaluated during the fermentation period. Tannase enzyme assay, hydrolyzable tannin content, sugar and protein content were estimated during the fermentation.

\section{Determination of concentration of sugar}

For all the three types of culture- $A$. niger, R. oryzae and Mixed Culture, substrate concentration of $20 \mathrm{~g}$ showed maximum production of sugar: A. niger-3.07 $\mathrm{mg}\left(11^{\text {th }} \mathrm{d}\right), R$. oryzae-2.97 $\mathrm{mg}$ $\left(12^{\text {th }} \mathrm{d}\right)$ and Mixed culture-3.11 $\mathrm{mg}\left(11^{\text {th }} \mathrm{d}\right)$. The change in sugar concentration was represented table 1, 2 and 3 and fig. 1, 2 and 3 .

Table 2: Estimation of sugar concentration (mg) during fermentation of various concentrations of substrate using Rhizopus oryzae

\begin{tabular}{|c|c|c|c|c|c|c|}
\hline \multirow[t]{2}{*}{ S. No. } & \multirow[t]{2}{*}{ Incubation time in days } & \multicolumn{5}{|c|}{ Substrate concentration (g) } \\
\hline & & 5 & 10 & 15 & 20 & 25 \\
\hline 1 & 0 & 0.46 & 0.67 & 0.71 & 0.72 & 0.55 \\
\hline 2 & 1 & 0.48 & 0.84 & 0.88 & 0.76 & 0.62 \\
\hline 3 & 2 & 0.51 & 0.96 & 0.97 & 0.89 & 0.78 \\
\hline 4 & 3 & 0.59 & 1.09 & 1.13 & 1.11 & 0.83 \\
\hline 5 & 4 & 0.63 & 1.21 & 1.16 & 1.43 & 0.97 \\
\hline 6 & 5 & 0.68 & 1.34 & 1.21 & 1.51 & 1.03 \\
\hline 7 & 6 & 0.74 & 1.56 & 1.33 & 1.94 & 1.08 \\
\hline 8 & 7 & 0.79 & 1.59 & 1.51 & 2.13 & 1.21 \\
\hline 9 & 8 & 0.81 & 1.63 & 1.79 & 2.44 & 1.26 \\
\hline 10 & 9 & 0.89 & 1.70 & 2.01 & 2.71 & 1.31 \\
\hline 11 & 10 & 0.97 & 1.89 & 2.25 & 2.82 & 1.51 \\
\hline 12 & 11 & 0.86 & 1.73 & 2.61 & 2.97 & 1.32 \\
\hline 13 & 12 & 0.83 & 1.51 & 2.03 & 1.91 & 1.01 \\
\hline 14 & 13 & 0.73 & 1.11 & 1.83 & 1.47 & 0.93 \\
\hline 15 & 14 & 0.47 & 1.03 & 1.12 & 1.11 & 0.41 \\
\hline 16 & 15 & 0.27 & 0.91 & 0.93 & 0.85 & 0.36 \\
\hline
\end{tabular}

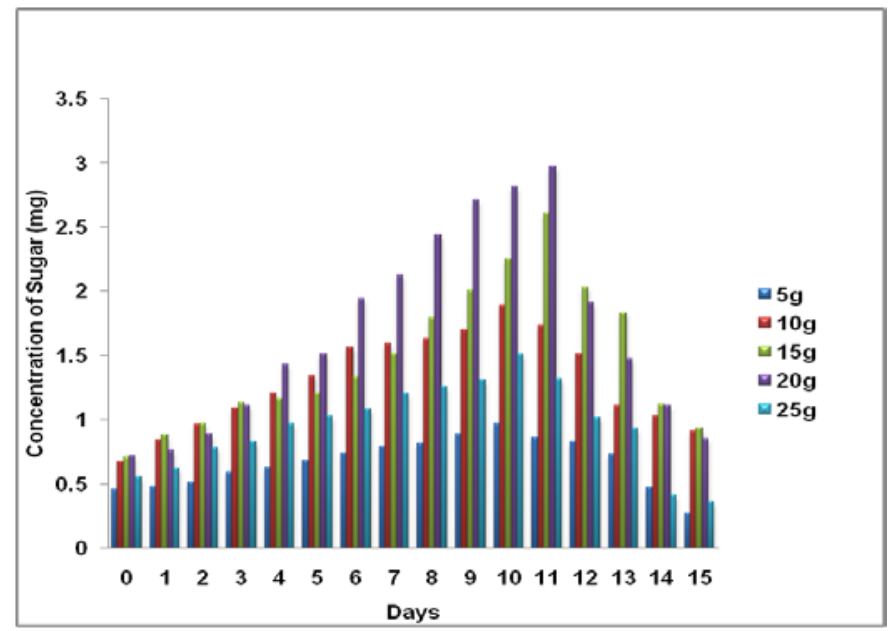

Fig. 2: Estimation of the concentration of sugar (mg) during fermentation of various concentrations of the substrate using Rhizopus oryzae

Table 3: Estimation of sugar concentration (mg) during fermentation of various concentrations of substrate using mixed culture

\begin{tabular}{|c|c|c|c|c|c|c|}
\hline \multirow[t]{2}{*}{ S. No. } & \multirow[t]{2}{*}{ Incubation time in days } & \multicolumn{5}{|c|}{ Substrate concentration (g) } \\
\hline & & 5 & 10 & 15 & 20 & 25 \\
\hline 1 & 0 & 0.46 & 0.67 & 0.71 & 0.72 & 0.55 \\
\hline 2 & 1 & 0.56 & 0.79 & 0.91 & 0.99 & 0.67 \\
\hline 3 & 2 & 0.62 & 0.98 & 1.14 & 1.24 & 0.92 \\
\hline 4 & 3 & 0.73 & 1.11 & 1.39 & 1.53 & 1.07 \\
\hline 5 & 4 & 0.89 & 1.25 & 1.74 & 1.79 & 1.21 \\
\hline 6 & 5 & 0.97 & 1.41 & 1.92 & 2.09 & 1.33 \\
\hline 7 & 6 & 1.02 & 1.59 & 2.09 & 2.51 & 1.41 \\
\hline 8 & 7 & 1.11 & 1.84 & 2.41 & 2.75 & 1.53 \\
\hline 9 & 8 & 1.37 & 2.04 & 2.73 & 3.01 & 1.81 \\
\hline 10 & 9 & 1.51 & 2.17 & 3.01 & 3.06 & 1.94 \\
\hline 11 & 10 & 1.41 & 2.51 & 3.11 & 3.11 & 1.98 \\
\hline 12 & 11 & 1.33 & 2.49 & 2.91 & 2.91 & 1.83 \\
\hline 13 & 12 & 1.17 & 2.21 & 2.17 & 2.11 & 1.41 \\
\hline 14 & 13 & 0.83 & 1.81 & 1.91 & 1.71 & 1.12 \\
\hline 15 & 14 & 0.71 & 1.47 & 1.43 & 1.42 & 0.97 \\
\hline 16 & 15 & 0.57 & 1.06 & 1.19 & 1.02 & 0.37 \\
\hline
\end{tabular}




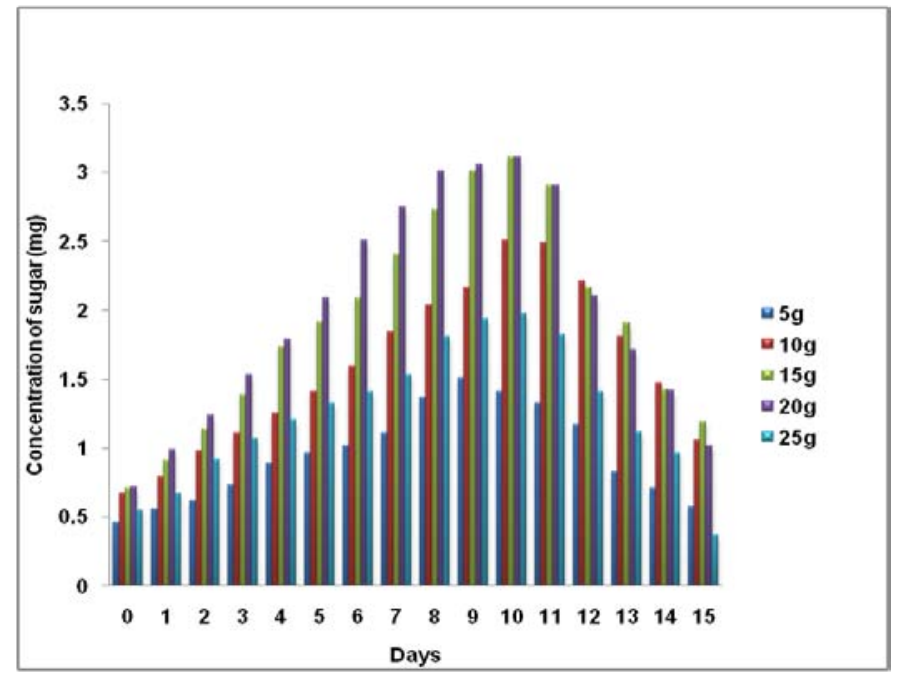

Fig. 3: Estimation of the concentration of sugar (mg) during fermentation of various concentrations of substrate using mixed culture

\section{Determination of concentration of soluble protein}

Protein concentration of the fermentation medium was analyzed as per Lowry method. Optimization studies of substrate concentration showed a varied result for analysis of soluble protein concentration between the chosen test organisms. For $A$. niger, a maximum concentration of soluble protein was obtained for the substrate concentration of $20 \mathrm{~g}-1.09 \mathrm{mg}$ on $12^{\text {th }} \mathrm{d}$; for $R$. oryzae and mixed culture, a maximum concentration of soluble protein was obtained for the substrate concentration of $15 \mathrm{~g}-1.03$ $\mathrm{mg}\left(11^{\text {th }} \mathrm{d}\right)$ and $1.09 \mathrm{mg}\left(12^{\text {th }} \mathrm{d}\right)$ respectively.

Table 4: Estimation of protein concentration (mg) during fermentation of various concentrations of substrate using Aspergillus niger

\begin{tabular}{|c|c|c|c|c|c|c|}
\hline \multirow[t]{2}{*}{ S. No. } & \multirow[t]{2}{*}{ Incubation time in days } & \multicolumn{5}{|c|}{ Substrate concentration (g) } \\
\hline & & 5 & 10 & 15 & 20 & 25 \\
\hline 1 & 0 & 0.09 & 0.18 & 0.21 & 0.27 & 0.19 \\
\hline 2 & 1 & 0.11 & 0.23 & 0.25 & 0.31 & 0.22 \\
\hline 3 & 2 & 0.21 & 0.29 & 0.33 & 0.35 & 0.34 \\
\hline 4 & 3 & 0.26 & 0.44 & 0.47 & 0.48 & 0.42 \\
\hline 5 & 4 & 0.45 & 0.59 & 0.51 & 0.54 & 0.47 \\
\hline 6 & 5 & 0.51 & 0.68 & 0.63 & 0.65 & 0.51 \\
\hline 7 & 6 & 0.56 & 0.75 & 0.76 & 0.79 & 0.54 \\
\hline 8 & 7 & 0.58 & 0.81 & 0.83 & 0.83 & 0.61 \\
\hline 9 & 8 & 0.41 & 0.86 & 0.95 & 0.89 & 0.68 \\
\hline 10 & 9 & 0.29 & 0.91 & 0.97 & 0.99 & 0.71 \\
\hline 11 & 10 & 0.23 & 0.93 & 1.01 & 1.03 & 0.73 \\
\hline 12 & 11 & 0.21 & 0.89 & 0.99 & 1.09 & 0.75 \\
\hline 13 & 12 & 0.18 & 0.83 & 0.85 & 0.97 & 0.61 \\
\hline 14 & 13 & 0.15 & 0.61 & 0.73 & 0.81 & 0.53 \\
\hline 15 & 14 & 0.12 & 0.59 & 0.68 & 0.69 & 0.39 \\
\hline 16 & 15 & 0.08 & 0.53 & 0.41 & 0.51 & 0.11 \\
\hline
\end{tabular}

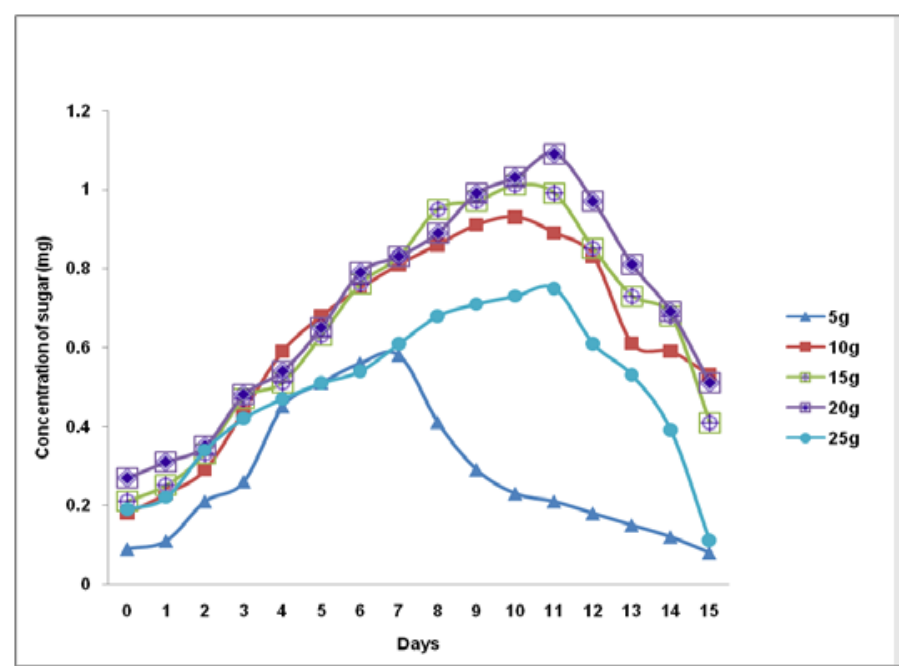

Fig. 4: Estimation of the concentration of protein (mg) during fermentation of various concentrations of substrate using Aspergillus niger 
Table 5: Estimation of protein concentration (mg) during fermentation of various concentrations of substrate using Rhizopus oryzae

\begin{tabular}{|c|c|c|c|c|c|c|}
\hline \multirow[t]{2}{*}{ S. No. } & \multirow[t]{2}{*}{ Incubation time in days } & \multicolumn{5}{|c|}{ Substrate concentration (g) } \\
\hline & & 5 & 10 & 15 & 20 & 25 \\
\hline 1 & 0 & 0.09 & 0.18 & 0.21 & 0.27 & 0.19 \\
\hline 2 & 1 & 0.12 & 0.21 & 0.26 & 0.29 & 0.21 \\
\hline 3 & 2 & 0.19 & 0.24 & 0.35 & 0.34 & 0.35 \\
\hline 4 & 3 & 0.25 & 0.32 & 0.48 & 0.46 & 0.37 \\
\hline 5 & 4 & 0.37 & 0.49 & 0.53 & 0.53 & 0.38 \\
\hline 6 & 5 & 0.49 & 0.57 & 0.64 & 0.61 & 0.41 \\
\hline 7 & 6 & 0.57 & 0.69 & 0.79 & 0.73 & 0.43 \\
\hline 8 & 7 & 0.63 & 0.78 & 0.85 & 0.79 & 0.49 \\
\hline 9 & 8 & 0.67 & 0.87 & 0.97 & 0.82 & 0.51 \\
\hline 10 & 9 & 0.71 & 0.93 & 1.01 & 0.87 & 0.52 \\
\hline 11 & 10 & 0.74 & 0.99 & 1.03 & 0.91 & 0.58 \\
\hline 12 & 11 & 0.79 & 1.02 & 0.99 & 0.90 & 0.61 \\
\hline 13 & 12 & 0.70 & 0.96 & 0.83 & 0.81 & 0.60 \\
\hline 14 & 13 & 0.62 & 0.61 & 0.71 & 0.72 & 0.52 \\
\hline 15 & 14 & 0.32 & 0.47 & 0.53 & 0.59 & 0.36 \\
\hline 16 & 15 & 0.21 & 0.23 & 0.18 & 0.37 & 0.19 \\
\hline
\end{tabular}

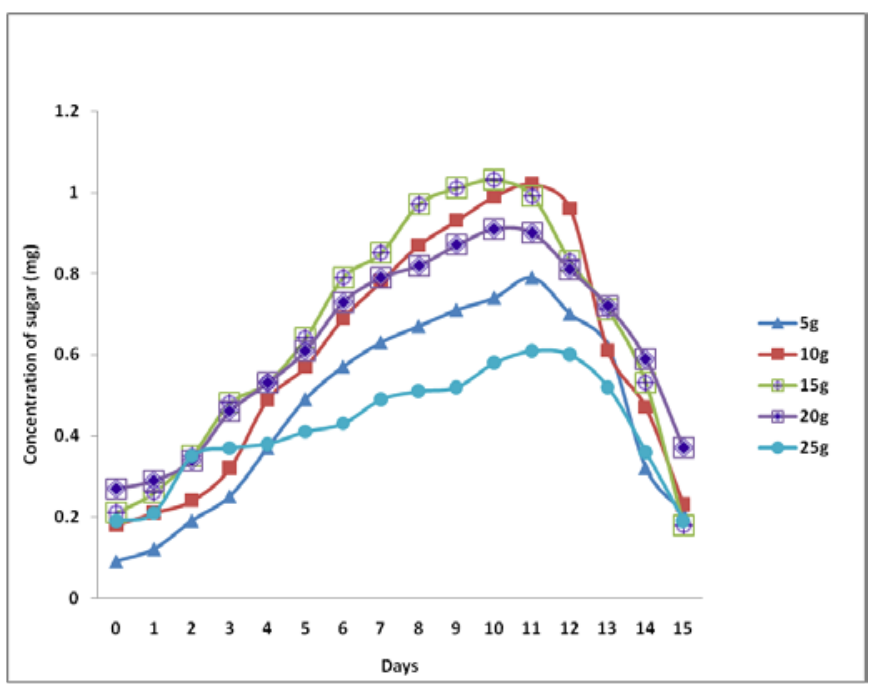

Fig. 5: Estimation of the concentration of protein (mg) during fermentation of various concentrations of substrate using Rhizopus oryzae

Table 6: Estimation of protein concentration (mg) during fermentation of various concentrations of substrate using mixed culture

\begin{tabular}{|c|c|c|c|c|c|c|}
\hline \multirow[t]{2}{*}{ S. No. } & \multirow[t]{2}{*}{ Incubation time in days } & \multicolumn{5}{|c|}{ Substrate concentration (g) } \\
\hline & & 5 & 10 & 15 & 20 & 25 \\
\hline 1 & 0 & 0.09 & 0.18 & 0.21 & 0.27 & 0.19 \\
\hline 2 & 1 & 0.12 & 0.22 & 0.27 & 0.32 & 0.21 \\
\hline 3 & 2 & 0.23 & 0.31 & 0.38 & 0.37 & 0.33 \\
\hline 4 & 3 & 0.25 & 0.39 & 0.49 & 0.46 & 0.45 \\
\hline 5 & 4 & 0.47 & 0.45 & 0.56 & 0.57 & 0.48 \\
\hline 6 & 5 & 0.53 & 0.60 & 0.67 & 0.68 & 0.51 \\
\hline 7 & 6 & 0.57 & 0.63 & 0.78 & 0.81 & 0.53 \\
\hline 8 & 7 & 0.61 & 0.76 & 0.83 & 0.85 & 0.58 \\
\hline 9 & 8 & 0.63 & 0.82 & 0.98 & 0.90 & 0.62 \\
\hline 10 & 9 & 0.48 & 0.88 & 1.03 & 0.97 & 0.67 \\
\hline 11 & 10 & 0.41 & 0.93 & 1.07 & 1.04 & 0.70 \\
\hline 12 & 11 & 0.39 & 0.97 & 1.09 & 1.01 & 0.64 \\
\hline 13 & 12 & 0.32 & 0.73 & 0.99 & 0.81 & 0.61 \\
\hline 14 & 13 & 0.27 & 0.64 & 0.79 & 0.63 & 0.59 \\
\hline 15 & 14 & 0.11 & 0.47 & 0.57 & 0.47 & 0.50 \\
\hline 16 & 15 & 0.06 & 0.28 & 0.21 & 0.39 & 0.17 \\
\hline
\end{tabular}

\section{Tannase enzyme assay}

Tannase enzyme indirectly shows the efficiency of test organisms in bioconversion of hydrolysable tannin to ellagic acid. Tannase enzyme activity was increased till $10^{\text {th }} \mathrm{d}$ for $A$. niger $(74.54$ units $/ \mathrm{ml}$ ), at the substrate concentration of $15 \mathrm{~g}$; for $R$. oryzae $(73.23$ units $/ \mathrm{ml}$ ), the maximum tannase activity obtained on $11^{\text {th }} \mathrm{d}$ of fermentation at the substrate concentration of $20 \mathrm{~g}$ and for mixed culture, maximum tannase activity ( 69.67 units $/ \mathrm{ml}$ ) was obtained on the $11^{\text {th }} \mathrm{d}$ of fermentation at the substrate concentration of $15 \mathrm{~g}$. After that, the tannase enzyme activity got decreased. The results were shown in table 7, 8 and 9 and fig. 7, 8 and 9. 


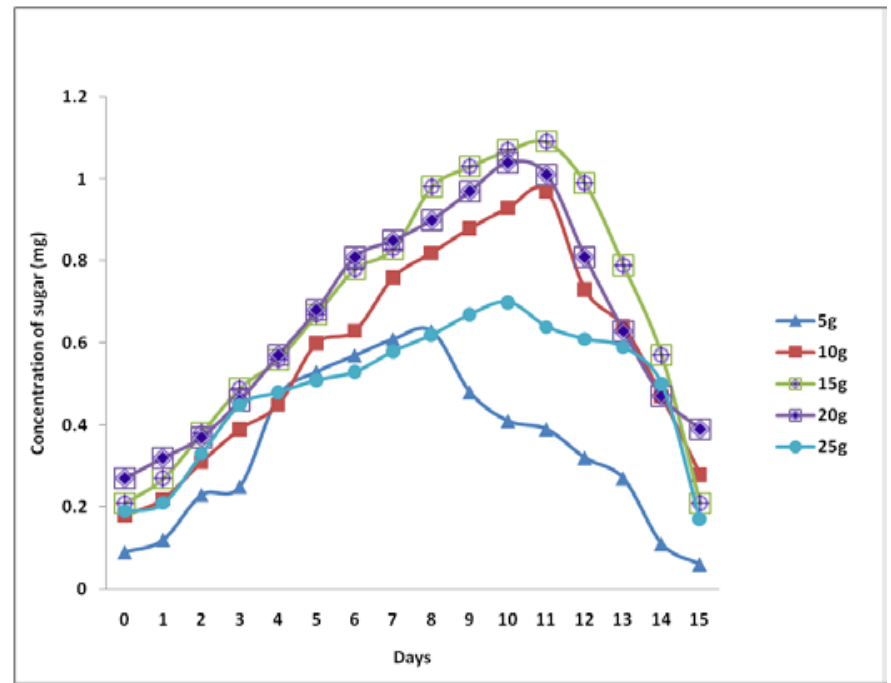

Fig. 6: Estimation of the concentration of protein $(\mathrm{mg})$ during fermentation of various concentrations of substrate using mixed culture

Table 7: Estimation of tannase enzyme (unit/ml) during fermentation of various concentrations of substrate using Aspergillus niger

\begin{tabular}{|c|c|c|c|c|c|c|}
\hline \multirow[t]{2}{*}{ S. No. } & \multirow[t]{2}{*}{ Incubation time in days } & \multicolumn{5}{|c|}{ Substrate concentration (g) } \\
\hline & & 5 & 10 & 15 & 20 & 25 \\
\hline 1 & 0 & 1.14 & 3.17 & 4.03 & 4.01 & 3.21 \\
\hline 2 & 1 & 2.45 & 7.12 & 9.33 & 10.37 & 5.33 \\
\hline 3 & 2 & 4.89 & 11.86 & 16.71 & 17.46 & 6.18 \\
\hline 4 & 3 & 6.71 & 15.37 & 21.45 & 25.14 & 6.23 \\
\hline 5 & 4 & 7.12 & 19.63 & 33.63 & 41.71 & 7.09 \\
\hline 6 & 5 & 7.93 & 23.54 & 39.88 & 48.82 & 7.28 \\
\hline 7 & 6 & 8.69 & 27.75 & 42.23 & 54.17 & 8.31 \\
\hline 8 & 7 & 9.27 & 35.45 & 47.16 & 59.24 & 8.47 \\
\hline 9 & 8 & 10.17 & 38.89 & 54.57 & 63.51 & 9.11 \\
\hline 10 & 9 & 10.86 & 44.54 & 58.59 & 68.85 & 10.06 \\
\hline 11 & 10 & 12.13 & 52.67 & 65.14 & 74.54 & 10.89 \\
\hline 12 & 11 & 9.08 & 50.32 & 51.79 & 61.43 & 8.50 \\
\hline 13 & 12 & 9.11 & 48.21 & 49.17 & 52.67 & 8.12 \\
\hline 14 & 13 & 8.82 & 41.48 & 41.11 & 49.63 & 7.03 \\
\hline 15 & 14 & 8.57 & 41.48 & 39.80 & 47.19 & 7.01 \\
\hline 16 & 15 & 7.32 & 39.12 & 21.50 & 33.12 & 5.81 \\
\hline
\end{tabular}

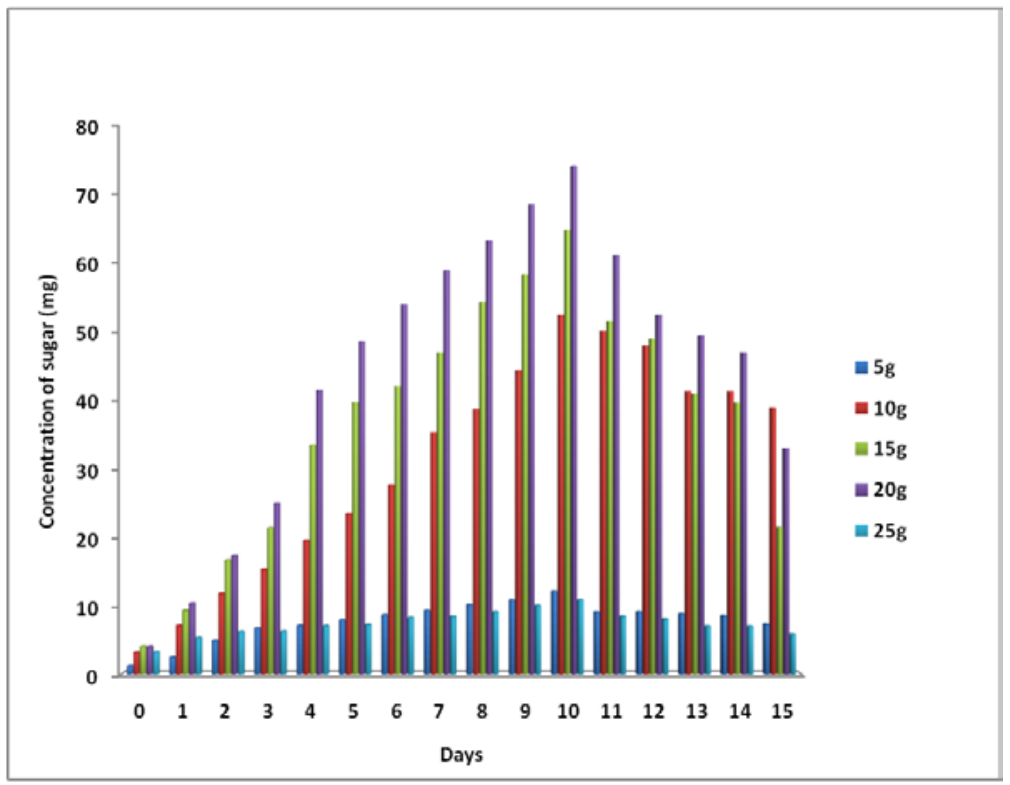

Fig. 7: Estimation of the concentration of tannase enzyme (Unit/ml) during fermentation of various concentrations of substrate using Aspergillus niger 
Table 8: Estimation of tannase enzyme (unit/ml) during fermentation of various concentration of substrate using Rhizopus oryzae

\begin{tabular}{|c|c|c|c|c|c|c|}
\hline \multirow[t]{2}{*}{ S. No. } & \multirow[t]{2}{*}{ Incubation time in days } & \multicolumn{5}{|c|}{ Substrate concentration (g) } \\
\hline & & 5 & 10 & 15 & 20 & 25 \\
\hline 1 & 0 & 1.14 & 3.17 & 4.03 & 4.01 & 3.21 \\
\hline 2 & 1 & 2.32 & 4.08 & 5.12 & 5.14 & 4.10 \\
\hline 3 & 2 & 4.16 & 9.61 & 7.29 & 6.17 & 4.21 \\
\hline 4 & 3 & 5.33 & 12.57 & 14.47 & 9.29 & 4.97 \\
\hline 5 & 4 & 5.97 & 17.81 & 25.08 & 17.93 & 5.11 \\
\hline 6 & 5 & 6.27 & 20.34 & 29.17 & 24.64 & 5.79 \\
\hline 7 & 6 & 6.83 & 33.56 & 43.14 & 41.37 & 6.14 \\
\hline 8 & 7 & 7.21 & 39.12 & 47.12 & 43.07 & 6.91 \\
\hline 9 & 8 & 9.37 & 43.68 & 54.91 & 52.21 & 8.23 \\
\hline 10 & 9 & 10.13 & 58.83 & 73.23 & 68.74 & 7.44 \\
\hline 11 & 10 & 10.11 & 54.75 & 71.19 & 59.81 & 6.70 \\
\hline 12 & 11 & 11.14 & 52.13 & 68.43 & 47.51 & 5.63 \\
\hline 13 & 12 & 10.37 & 58.47 & 53.86 & 42.15 & 3.81 \\
\hline 14 & 13 & 4.87 & 49.31 & 41.37 & 36.73 & 3.15 \\
\hline 15 & 14 & 3.70 & 37.80 & 38.58 & 33.57 & 2.97 \\
\hline 16 & 15 & 2.17 & 23.16 & 31.02 & 20.31 & 2.70 \\
\hline
\end{tabular}

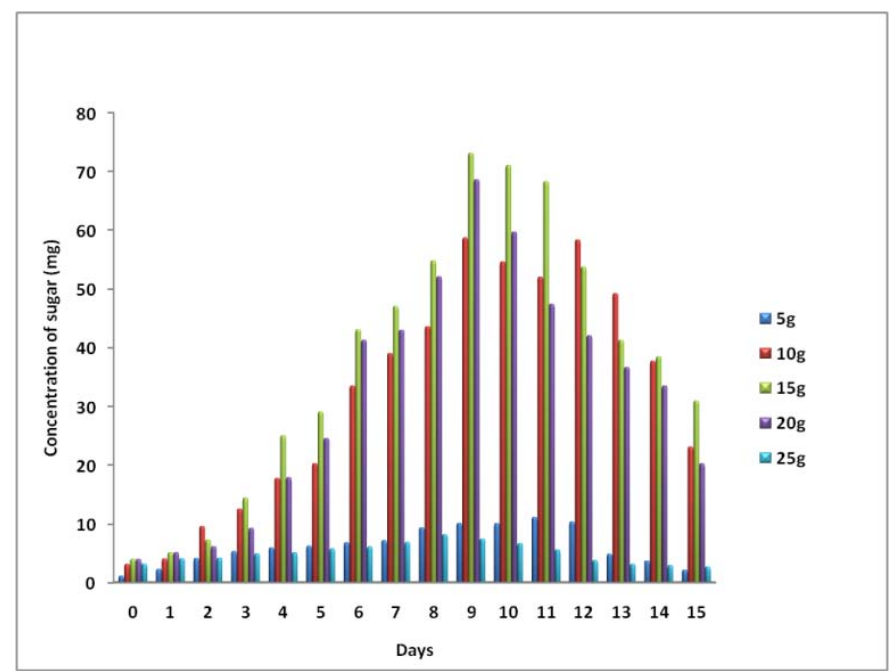

Fig. 8: Estimation of the concentration of tannase enzyme (Unit/ml) during fermentation of various concentrations of substrate using Rhizopus oryzae

Table 9: Estimation of tannase enzyme (unit/ml) during fermentation of various concentrations of substrate using mixed culture

\begin{tabular}{|c|c|c|c|c|c|c|}
\hline \multirow[t]{2}{*}{ S. No. } & \multirow[t]{2}{*}{ Incubation time in days } & \multicolumn{5}{|c|}{ Substrate concentration (g) } \\
\hline & & 5 & 10 & 15 & 20 & 25 \\
\hline 1 & 0 & 1.14 & 3.17 & 4.03 & 4.01 & 3.21 \\
\hline 2 & 1 & 2.61 & 6.87 & 10.28 & 9.14 & 5.27 \\
\hline 3 & 2 & 4.72 & 12.67 & 15.81 & 16.33 & 5.08 \\
\hline 4 & 3 & 5.58 & 16.11 & 17.64 & 23.54 & 5.24 \\
\hline 5 & 4 & 7.03 & 18.34 & 25.53 & 28.62 & 5.87 \\
\hline 6 & 5 & 7.82 & 21.73 & 34.16 & 43.71 & 6.11 \\
\hline 7 & 6 & 8.11 & 26.81 & 41.75 & 47.17 & 6.45 \\
\hline 8 & 7 & 8.64 & 34.09 & 43.62 & 52.42 & 6.22 \\
\hline 9 & 8 & 10.23 & 39.22 & 49.15 & 54.85 & 7.04 \\
\hline 10 & 9 & 10.44 & 45.21 & 52.36 & 65.28 & 8.32 \\
\hline 11 & 10 & 13.34 & 49.49 & 57.29 & 69.67 & 9.63 \\
\hline 12 & 11 & 9.21 & 50.47 & 42.32 & 56.74 & 8.57 \\
\hline 13 & 12 & 9.06 & 47.89 & 38.17 & 51.37 & 7.12 \\
\hline 14 & 13 & 7.48 & 32.01 & 36.86 & 37.83 & 6.76 \\
\hline 15 & 14 & 7.63 & 29.93 & 29.63 & 31.88 & 5.99 \\
\hline 16 & 15 & 6.08 & 11.61 & 20.19 & 18.73 & 3.29 \\
\hline
\end{tabular}

\section{Estimation of hydrolysable tannin}

The chosen fungi reduce the high tannin content in pomegranate peels demonstrating the ability of the fungal strain to degrade hydrolysable tannins. No reduction of tannin was observed in the control. Similar results were given by Ventura et al., [14] stating that the concentration of tannin got reduced at the end of fermentation.
For A. niger initial tannin content of $1.27 \mathrm{mg} / \mathrm{g}$ of substrate $(20 \mathrm{~g})$ was found to be reduced to $0.29 \mathrm{mg} / \mathrm{g}$ at the end of fermentation; for $R$. oryzae initial tannin content was found to be $1.35 \mathrm{mg} / \mathrm{g}$ of substrate (15g) which got reduced during fermentation. After fermentation tannin content was reduced to $0.57 \mathrm{mg} / \mathrm{g}$. And for mixed culture, initial tannin content of $1.27 \mathrm{mg} / \mathrm{g}$ of $20 \mathrm{~g}$ substrate got reduced to $0.52 \mathrm{mg} / \mathrm{g}$ at the end of fermentation. 


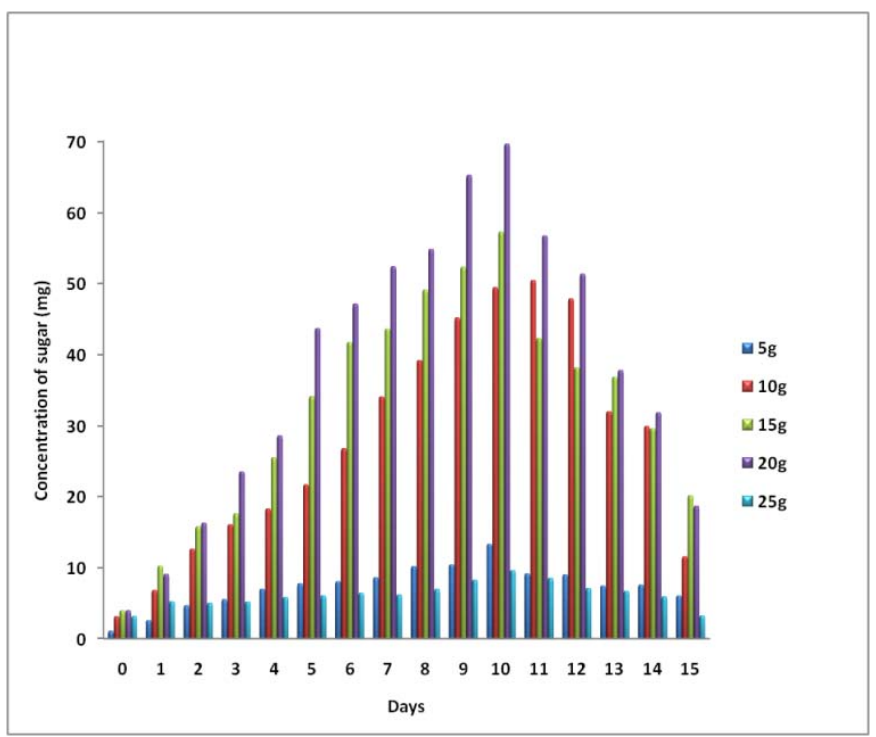

Fig. 9: Estimation of the concentration of tannase enzyme (Unit/ml) during fermentation of various concentrations of substrate using mixed culture

Table 10: Estimation of tannin (mg) during fermentation of various concentrations of substrate using Aspergillus niger

\begin{tabular}{|c|c|c|c|c|c|c|}
\hline \multirow[t]{2}{*}{ S. No. } & \multirow[t]{2}{*}{ Incubation time in days } & \multicolumn{5}{|c|}{ Substrate concentration (g) } \\
\hline & & 5 & 10 & 15 & 20 & 25 \\
\hline 1 & 0 & 0.96 & 1.22 & 1.35 & 1.27 & 0.85 \\
\hline 2 & 1 & 0.98 & 1.19 & 1.27 & 1.16 & 0.81 \\
\hline 3 & 2 & 0.91 & 1.23 & 1.21 & 0.86 & 0.77 \\
\hline 4 & 3 & 0.85 & 1.08 & 1.11 & 0.81 & 0.75 \\
\hline 5 & 4 & 0.79 & 0.96 & 1.03 & 0.74 & 0.69 \\
\hline 6 & 5 & 0.73 & 0.93 & 0.99 & 0.67 & 0.63 \\
\hline 7 & 6 & 0.64 & 0.85 & 0.95 & 0.63 & 0.58 \\
\hline 8 & 7 & 0.62 & 0.79 & 0.86 & 0.59 & 0.54 \\
\hline 9 & 8 & 0.57 & 0.74 & 0.82 & 0.45 & 0.49 \\
\hline 10 & 9 & 0.55 & 0.68 & 0.77 & 0.36 & 0.44 \\
\hline 11 & 10 & 0.43 & 0.64 & 0.53 & 0.29 & 0.37 \\
\hline 12 & 11 & 0.38 & 0.62 & 0.41 & 0.23 & 0.32 \\
\hline 13 & 12 & 0.21 & 0.53 & 0.22 & 0.15 & 0.20 \\
\hline 14 & 13 & 0.19 & 0.39 & 0.17 & 0.13 & 0.09 \\
\hline 15 & 14 & 0.11 & 0.31 & 0.16 & 0.09 & 0.08 \\
\hline 16 & 15 & 0.09 & 0.27 & 0.13 & 0.07 & 0.04 \\
\hline
\end{tabular}

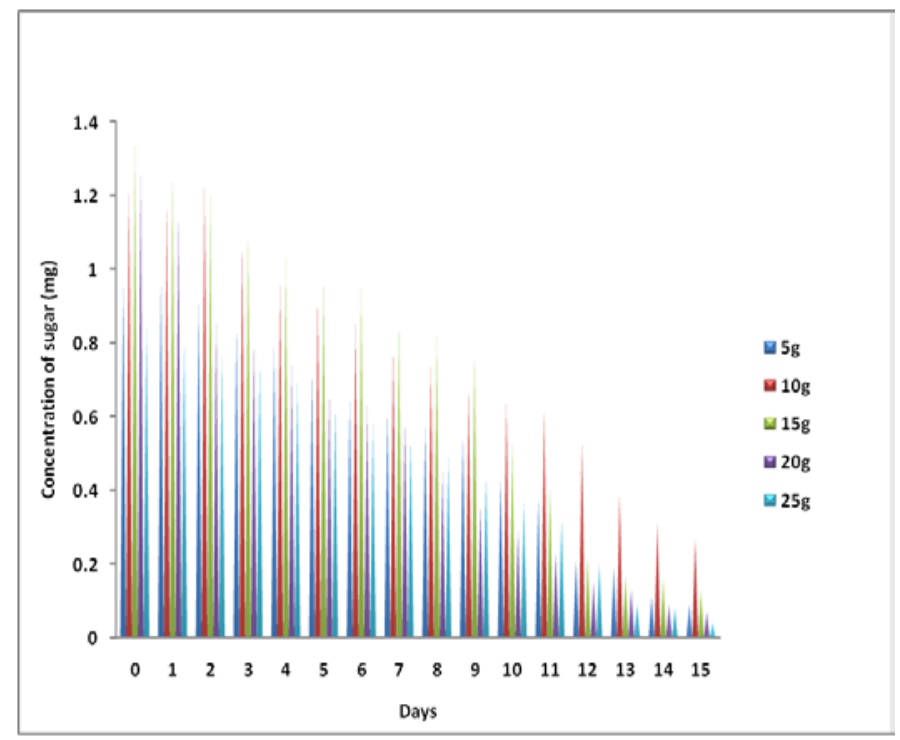

Fig. 10: Estimation of the concentration of tannin (mg) during fermentation of various concentrations of substrate using Aspergillus niger 
Table 11: Estimation of tannin content (mg) during fermentation of various concentration of substrate using Rhizopus oryzae

\begin{tabular}{|c|c|c|c|c|c|c|}
\hline \multirow[t]{2}{*}{ S. No. } & \multirow[t]{2}{*}{ Incubation time in days } & \multicolumn{5}{|c|}{ Substrate concentration (g) } \\
\hline & & 5 & 10 & 15 & 20 & 25 \\
\hline 1 & 0 & 0.96 & 1.22 & 1.35 & 1.27 & 0.85 \\
\hline 2 & 1 & 0.93 & 1.22 & 1.24 & 1.09 & 0.78 \\
\hline 3 & 2 & 0.84 & 1.20 & 1.19 & 0.94 & 0.73 \\
\hline 4 & 3 & 0.78 & 1.14 & 1.13 & 0.87 & 0.67 \\
\hline 5 & 4 & 0.71 & 1.07 & 1.09 & 0.82 & 0.64 \\
\hline 6 & 5 & 0.65 & 1.01 & 0.89 & 0.79 & 0.55 \\
\hline 7 & 6 & 0.63 & 0.86 & 0.85 & 0.68 & 0.47 \\
\hline 8 & 7 & 0.56 & 0.83 & 0.83 & 0.64 & 0.41 \\
\hline 9 & 8 & 0.54 & 0.77 & 0.74 & 0.53 & 0.38 \\
\hline 10 & 9 & 0.47 & 0.74 & 0.57 & 0.44 & 0.33 \\
\hline 11 & 10 & 0.43 & 0.69 & 0.48 & 0.39 & 0.27 \\
\hline 12 & 11 & 0.35 & 0.65 & 0.37 & 0.24 & 0.26 \\
\hline 13 & 12 & 0.24 & 0.54 & 0.24 & 0.19 & 0.17 \\
\hline 14 & 13 & 0.17 & 0.41 & 0.21 & 0.16 & 0.08 \\
\hline 15 & 14 & 0.13 & 0.26 & 0.19 & 0.07 & 0.06 \\
\hline 16 & 15 & 0.08 & 0.17 & 0.11 & 0.07 & 0.03 \\
\hline
\end{tabular}

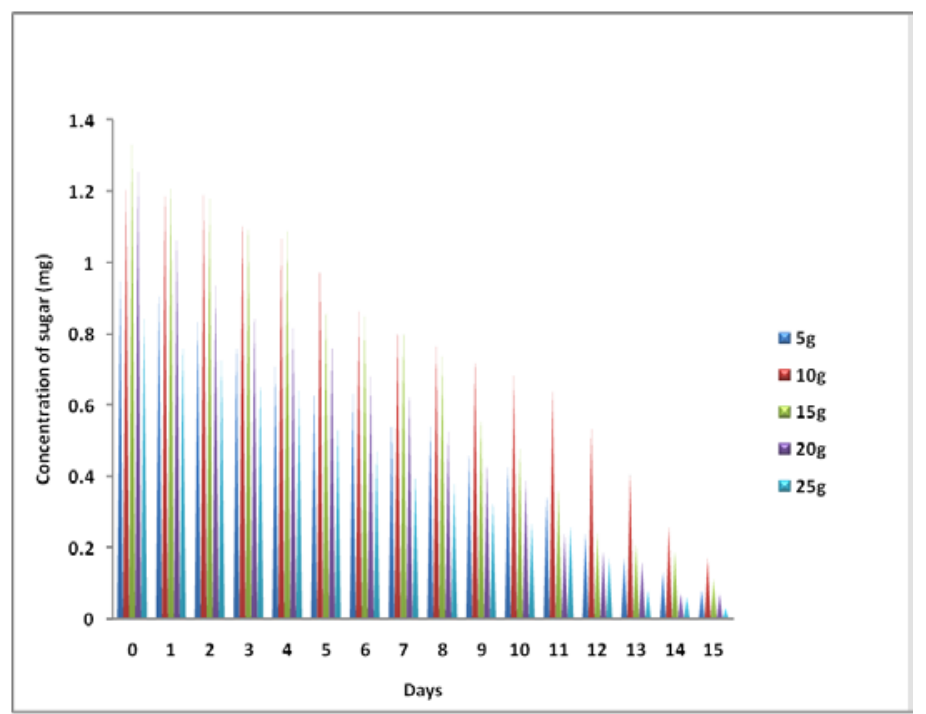

Fig. 11: Estimation of concentration of tannin (mg) during fermentation of various concentration of substrate using Rhizopus oryzae

Table 12: Estimation of tannin content (mg) during fermentation of various concentration of substrate using mixed culture

\begin{tabular}{|c|c|c|c|c|c|c|}
\hline \multirow[t]{2}{*}{ S. No. } & \multirow[t]{2}{*}{ Incubation time in days } & \multicolumn{5}{|c|}{ Substrate concentration (g) } \\
\hline & & 5 & 10 & 15 & 20 & 25 \\
\hline 1 & 0 & 0.96 & 1.22 & 1.35 & 1.27 & 0.85 \\
\hline 2 & 1 & 0.91 & 1.12 & 1.21 & 1.19 & 0.83 \\
\hline 3 & 2 & 0.83 & 1.03 & 1.17 & 1.11 & 0.78 \\
\hline 4 & 3 & 0.77 & 0.99 & 1.08 & 1.01 & 0.72 \\
\hline 5 & 4 & 0.69 & 0.93 & 0.97 & 0.95 & 0.67 \\
\hline 6 & 5 & 0.62 & 0.88 & 0.92 & 0.87 & 0.63 \\
\hline 7 & 6 & 0.58 & 0.82 & 0.85 & 0.81 & 0.56 \\
\hline 8 & 7 & 0.54 & 0.77 & 0.79 & 0.78 & 0.49 \\
\hline 9 & 8 & 0.51 & 0.70 & 0.73 & 0.69 & 0.45 \\
\hline 10 & 9 & 0.46 & 0.63 & 0.68 & 0.57 & 0.39 \\
\hline 11 & 10 & 0.42 & 0.59 & 0.61 & 0.52 & 0.34 \\
\hline 12 & 11 & 0.35 & 0.54 & 0.57 & 0.49 & 0.30 \\
\hline 13 & 12 & 0.29 & 0.42 & 0.52 & 0.40 & 0.26 \\
\hline 14 & 13 & 0.22 & 0.37 & 0.48 & 0.36 & 0.21 \\
\hline 15 & 14 & 0.18 & 0.25 & 0.39 & 0.27 & 0.18 \\
\hline 16 & 15 & 0.12 & 0.13 & 0.27 & 0.21 & 0.14 \\
\hline
\end{tabular}

The results of the present investigation demonstrated the optimum substrate concentration for the active conversion of ellagitannins to ellagic was $15 \mathrm{~g}$ of $A$. niger, $20 \mathrm{~g}$ for $R$. oryzae and $15 \mathrm{~g}$ for mixed culture. Similar results were given be Aguilar et al., [15] by using Pomegranate peel and Creosote bush as the substrate for the production of ellagic acid. Saxena and Batra, [16] reported the optimum concentration of substrate (Myrobolan Powder) was $11.6 \%$. 


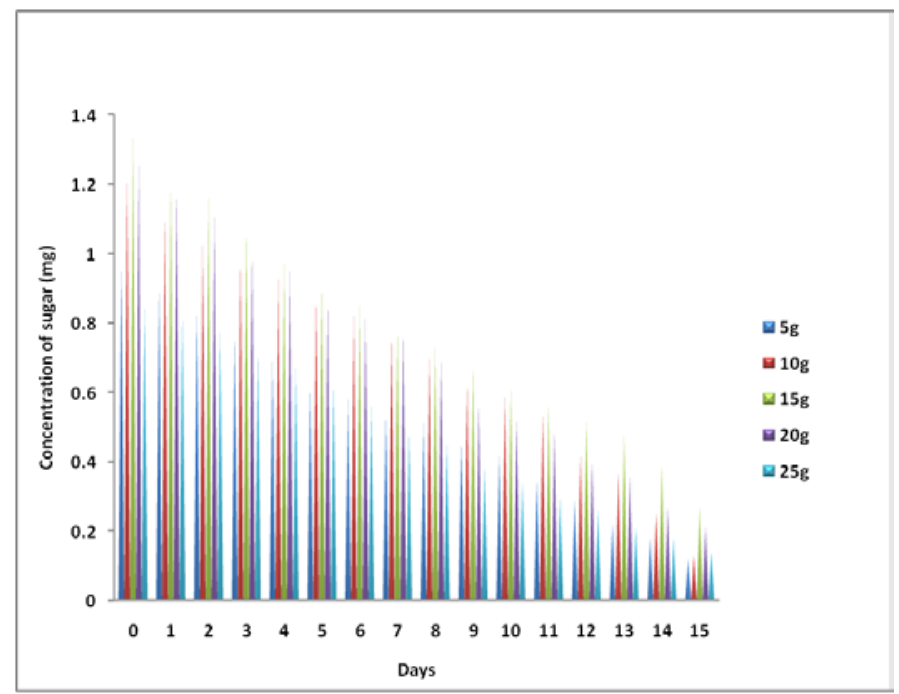

Fig. 12: Estimation of the concentration of tannin ( $\mathrm{mg}$ ) during fermentation of various concentrations of substrate using mixed culture

\section{CONCLUSION}

Solid-state bioprocessing of fruit substrates and fruit wastes using fungi has been shown to enrich phenolic antioxidants and improve phytochemical consistency. Ellagic acid, a phenolic antioxidant has been studied mainly for their positive effect on human health and for their physiological properties such as anti-tumor, antiviral and antibacterial activities. Industrially ellagic acids are used in creams and other cosmetic products which show significant use in clearing the skin. The peels of Pomegranate (Punica granatum L.) are a rich source of phenolic compounds like hydrolyzable ellagitannins that possess strong antioxidant activities. From the present investigation, it can be concluded that Pomegranate Peel Extract (PPE) serves as a rich source of ellagitannins which could be converted to Ellagic acid by the filamentous fungi.

\section{FUNDING}

$\mathrm{Nil}$

\section{AUTHORS CONTRIBUTIONS}

All the authors have contributed equally.

\section{CONFLICT OF INTERESTS}

\section{Declared none}

\section{REFERENCES}

1. Kusmardi Kusmardi, Dony Hermanto, Ari Estuningytas, Aryo Tedjo, Bambang P Priosoeryanto. The potency of Indonesia's pomegranate peel ethanol extract (Punica granatum linn.) as anti-inflammatory agent in mice colon induced by dextran sodium sulfate: focus on cyclooxygenase- 2 and Inos expressions. Asian J Pharm Clin Res 2017;10:370-5.

2. Kar B, Banerjee R. Biosynthesis of tannin acyl hydrolase from tannin-rich forest residue under different fermentation conditions. J Ind Microbiol Biotechnol 2000;25:29-38.

3. Manjit YA, Aggarwal NK, Kumar K, Kumar A. Tannase production by Aspergillus fumigatus MA under solid-state fermentation. World J Microbiol Biotechnol 2008;24:3023-30.

4. Ya-ming $\mathrm{Xu}$, Jing-Zhen Deng, Ji Ma, Shao-Nong Chen, Rebekah Marshall, Shannon H Jones, et al. DNA damaging activity of ellagic acid derivatives. Bioorg Med Chem 2003;11:1593-6.
5. Palanisamy Malini, Ganesan Kanchana, Murugan Rajadurai. Antibiabetic efficacy of ellagic acid in streptozotocin induced diabetes mellitus in albino wistar rats. Asian J Pharm Clin Res 2011;4:124128.

6. Sultana Shaikh, Vandana Jain. Development and validation of novel RP-HPLC method for the simultaneous estimation of ellagic acid and quercetin in an ayurvedic formulation. Int J Appl Pharm 2018;10:111-6.

7. Kadhem K, Ghudhaib, Ekbal R Hanna, Alaa Hussein Jawad. Effect of ellagic acid on some types of pathogenic bacteria. J AlNahrain Univ 2010;13:79-85.

8. Aguilar CN, Torres EF, Gonzalez GV, C Augur. Culture conditions dictate protease and tannase production in submerged and solid-state cultures of Aspergillus niger Aa-20. Appl Biochem Biotechnol 2002;102:407-14.

9. Rakesh Kumar, Jitender Sharma, Randhir Singh. Production of tannase from Aspergillus ruber under solid-state fermentation using jamun (Syzygium cumini) leaves. Microb Res 2007;162:384-90.

10. Pinto GAS, Leite SGF, Terzi SC, S Couri. Selection of tannaseproducing Aspergillus niger strains. Braz J Microbiol 2001;32:24-6.

11. Anita Srivastava, Rita Kar. Characterization and application of tannase produced by Aspergillus niger ITCC 6514.07 on pomegranate rind. Braz J Microbiol 2009;40:782-9.

12. Keshab C Mondal, Debdulal Banerjee, Rintu Banerjee, Bikas R Pati. Production and characterization of tannase from Bacillus cereus KBR9. J Gen Appl Microbiol 2001;47:263-7.

13. Mondal KC, Banerjee D, Tana M, Pati BR. Calorimetric assay method for determination of the tannic acids hydrolase activity. Anal Biochem 2001;295:168-71.

14. Ventura J, Belmares Cerda R, Aguilera Carbo A, Contreras Esquivel JC, Rodríguez Herrera R, Aguilar CN. Fungal biodegradation of tannins from creosote bush (Larrea tridentata) and tar bush (Fluorensia cernua) for gallic and ellagic acid production. Food Technol Biotechnol 2007;46:213-7.

15. Aguilar CN, Aguilera Carbo A, Robledo Olivo A, Ventura J, Belmares Cerda R, Martinez D, et al. Production of antioxidants and nutraceuticals by solid-state cultures of pomegranate (Punica granatum) peel and creosote bush (Larrea tridentata) leaves. Food Technol Biotechnol 2008;46:218-22.

16. Saxena RK, Batra A. Potential tannase producers from the genera Aspergillus and Penicillium. Process Biochem 2004;40:1553-7. 